\title{
Heroism and Sublimity Characteristics in Chopin's Scherzo
}

\author{
Xiaorong Wang
}

\author{
School of Music, Qilu Normal University, Ji'nan Shandong, 250100, China
}

Key Words: Chopin, Scherzo, Heroism, Tragedy.

\begin{abstract}
Chopin creates four scherzos throughout three creative periods in his lifetime, which grasp the essence of humor and make it connected with characteristics like satire, dignity, sublimity, heroism, tragedy, etc. These four works get rid of vulgarity and sensationalism, improving the aesthetic category of scherzo to a more prominent level and equipping it with more profound ideological contents and philosophy on basis of humor. This paper focuses on the discussion of how sublimity and heroism are implanted into Chopin's scherzos.
\end{abstract}

\section{Text}

After the French Revolution, some new characteristics such as the change of tone, emotional excitement and open artistic conception appeared in European romantic trend. In all kinds of art like music, fine art, poetry and drama, representation of "hero" has already become France's special contribution to the $19^{\text {th }}$ century romanticism, but heroes are always closely linked with tragedy. One kind of tragedy is heroic tragedy, the theme of which is usually closely related to society, politics and national struggle. In such kind of theme, suffering from the threat of hardship or death, strong will and endless courage in the heart of the leading character will be aroused to defeat the tragic emotion and therefore form the heroic spirit. In general, heroes are equipped with sublime quality, shouldering the historical burden related to national prosperity and decline. With indomitable spirit, they are able to reach "everlasting victory” after suffering from all kinds of torture.

In musical field, the pursuit of heroism has never been interrupted. It is not an initial attempt for Chopin to represent the connotation of heroism and sublimity in form of scherzos. This exploration began in Beethoven period. During the $18^{\text {th }}$ century classical period when the wave of the French Revolution swept Europe, bourgeoisie's power was even stronger, and the whole society was praising heroes and pursuing eternal truth, "heroism" is a significant and inevitable aspect in the work of Beethoven who was the model of that age. However, at the earlier stage of romanticism in the first half of $19^{\text {th }}$ century when the aftermath of the French Revolution had not gone, the national-democratic revolution trend of European countries arose as surge. Pursuit of heroes is still the dream unchanged in people's heart, but the image and connotation of "heroes" has been changed quietly. At that time, Dionysian Spirit gradually occupied the dominant position and composers paid the most attention to the hottest expression of inner feeling. A French symbolistic poet, named Charles Baudelaire, once defined romanticism as "romanticism is neither random materials nor emphasis on completely accurate, but the intermediate point of both parts, which follows the feelings". It is the time that breeds the heroic spirit with humanized characteristics in Chopin's scherzos.

Grout in his A History of Western Music once said as follows:

The fundamental features of Chopin style are elaborated by large area in ballade and scherzo. He is obviously the first one who applies ballade into instrumental music. Composition (especially G minor Op.23 and $\mathrm{f}$ minor Op.52) written in this form grasps the ballades' beauty and passion of a great Poland poet Adam Mickiewicz, and makes them combined with indescribable spontaneity and 6699j 
turn whose harmony and musical form make new advances constantly (all these have become the unique label of Chopin). Several major scherzos are b minor (Op.20) and c sharp minor (Op.39). Chopin's scherzo is mostly serious, energetic and passionate works like ballade without original naughty sense of this type. It is orderly organized in the compact form of musical thoughts generated naturally.

In above statement, Grout takes the First Scherzo of b Minor (Op.20) and the Third Scherzo of c Sharp Minor (Op.39) as the significant representative works of Chopin, which are exactly the best interpretation for "heroism". It can be seen from the works that Chopin follows the trend of the times the French Revolution has brought to musical field. Language in form of piano and poem adds tragic color to romantic heroes. In the two scherzos of Chopin, the writer firmly takes music as a spiritual attitude originating from Beethoven who adores heroes more. Beethoven's Third Symphony, Fifth Symphony and First Sonata of f Minor (Op.2.No.1) have all revealed people's fight for dominating the world and infinite praise of heroes. Heroes in Chopin's music are deeply rooted in his own nation. As is said by Belinski, a poet can not be great because of himself or by relying on himself. His greatness is connected with neither his own hardship nor his own happiness. The reason why a great poet can be great is that his hardship and happiness are deeply rooted in social and historical soil. Through above analysis, it shows that Chopin's scherzos are closely linked with folk music of homeland, but what the writer has shaped in scherzos is hero with great feelings which are rooted in history and society.

Analysis above shows us that Chopin's first scherzo and third scherzo is the works with the most tragic power, but tragedy is exactly the process where people experience hardship and death. When tragedy and destruction finally come, the resistance consciousness and vigorous vitality shown by the leading character will stimulate people's sublimity and awe. It is the heroic spirit and sense of lofty represented in artistic works with tragic characteristics. However, due to the hardship and death suffered by compatriots, generated sense of frustration in inner world and strong rebound of spiritual strength, Chopin, as a Poland national hero in musical field, creates the source of heroism and sublimity in scherzos (First Scherzo of b Flat Minor (Op.20) and the Third Scherzo of c Sharp Minor (Op. 39)). Kant once mentioned in his Critique of Judgment that each kind of passion (it is the animi strenui that motivates us to overcome all resistance) with heroic quality such as anger and even desperation (that is to say, the angry desperation rather than depressed desperation) is aesthetically sublime. At this point, both works have extremely strong similarity. They stimulate audiences' strength with furious first theme and then serve as a foil to a series of negative emotions like excitement, restlessness and embitterment with minor tonality.

The First Scherzo of b Minor (Op.20) has very strong sound intensity, interval relations with high tonicity, and melodic line fluctuation as well as harmonic intensification at musical climax stage. However, we have already known through previous analysis that all these are closely linked with the social and historical background when the composer creates this work. This work was created during the failing period of Warsaw Revolution, so it apparently implied contents like being caught in hardship, struggling, embracing hope, getting rid of dilemma and acquiring immortality. As we all know, descending melodic line usually causes down emotion, while ascending melodic line causes rising emotion. Similarly, if the inconsonant effects in works are descending, emotional effects like depression and powerless resistance will be caused. But the writer conducts the melodic line in a rather acute perspective, so such kind of arrangement makes the melodic line with effects of fighting, blocking, and refighting. Therefore, the resistance force owned by tragic heroes is generated in the fluctuation of melodic line. While constantly showing restraining and fighting feelings, supernormal and firm willpower necessary for heroic spirit will also be shown gradually. The power for defeating all these obstacles has reached aesthetic sublimity which reveals the victory of moral spirit power. Like what Szabolesi Bence said that the keynote of all these melodies is mostly about heroism, war and excitement. They all tensely skitter upward, having sudden interval leap and unmeant exhaustion like the surge rolling in the sea. Melody comes out of its structure and is turned into a moving line, lifting enthusiastic climaxes and remotely breaking through the natural limit of sound.

Example of music score: The First Scherzo of b Flat Minor (Op.20) 


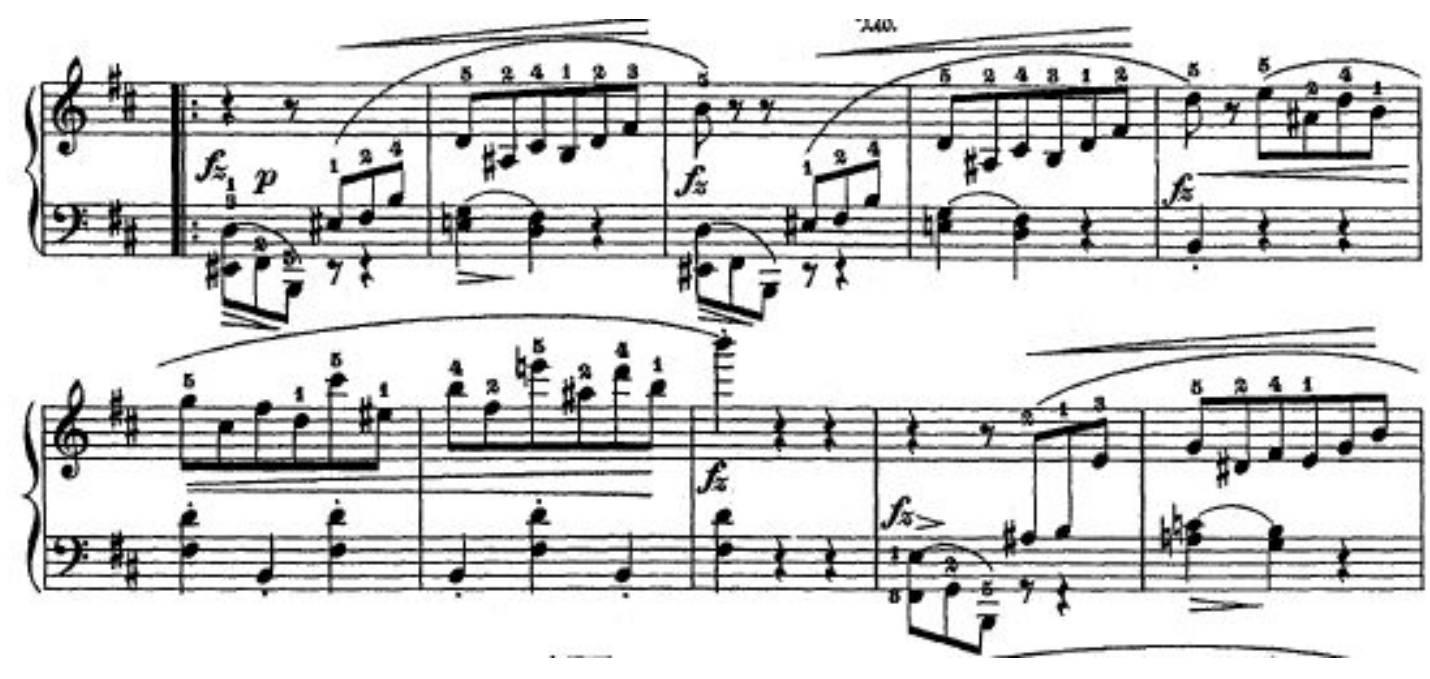

Fig. 1. Melodic line of theme phrase in First Scherzo of b Flat Minor (Op.20)

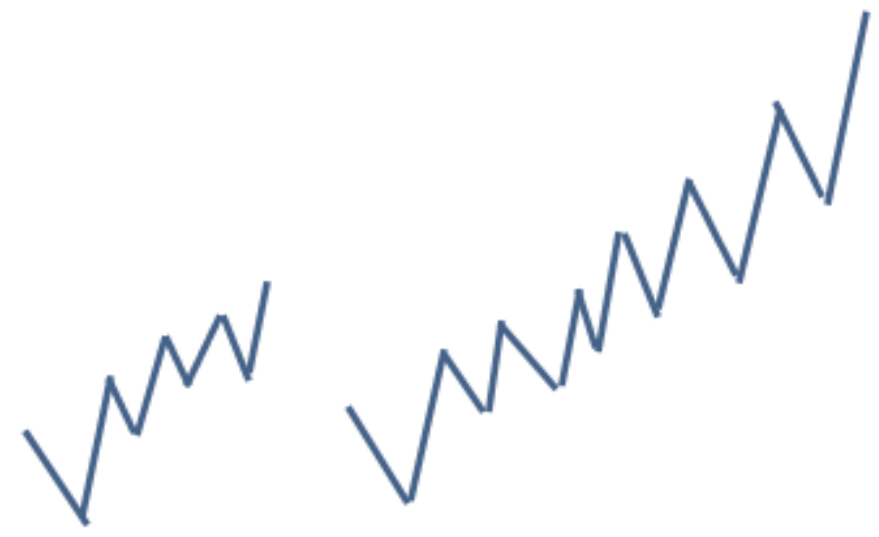

Works exactly use such kind of tragic hero passion to stimulate people's sense of sublimity. It can be seen from another perspective that the sublimity in the two works is actually mechanical sublimity. Kant in his Critique of Judgment divides sublimity into mathematic sublimity and mechanical sublimity. As for the latter one, he reckons:

Strength is a kind of ability superior to great obstacle. As for the same strength, when it is superior to the resistance which also has strength, it is called compelling force. When the natural world is taken as strength in aesthetic judgment but lacks compelling force for us, it is called the mechanical sublimity.

If we want to judge the natural world as mechanically sublime, it must be presented as something for stimulating fear (even though it can not be said in turn that each object that stimulates fear can be judged as mechanically sublime in aesthetic judgment), because in aesthetic judgment, the advantage of overcoming obstacles is merely judged in accordance with resistance. But now what we industriously resist is a kind of disaster. If we feel that our ability can not stand against the disaster and he himself is an object of fear, it can be considered as strength and then mechanical sublimity.

In another scherzo named Third Scherzo of c Sharp Minor (Op.39), its heroism and sublimity is generated in the same way. In addition, we can also appreciate another kind of expressive way of sublimity in this work. We all know that it was created during 1838 and 1842 when it is the second agonizing period of Paris (the first one was the failing period of Warsaw Uprising). This work is filled with restless negative emotions. In the frightening mechanical sublimity factors caused by this work, one of the most important reasons is to emphasize descending orthotropism melodic line. Without any softened factors, this melodic line causes direct, precipitous and deterrent feelings in accordance with the general characteristics of perceptual tone. In Third Scherzo of c Sharp Minor (Op.39), great otherness and contrariety exist between two themes, causing the dramatic tension of music. Main 
theme expresses contents of war. Parallel octaves are conducted stoutly and bring about a kind of irresistible pressure.

Example of music score: Chopin’s Third Scherzo of c Sharp Minor (Op.39)
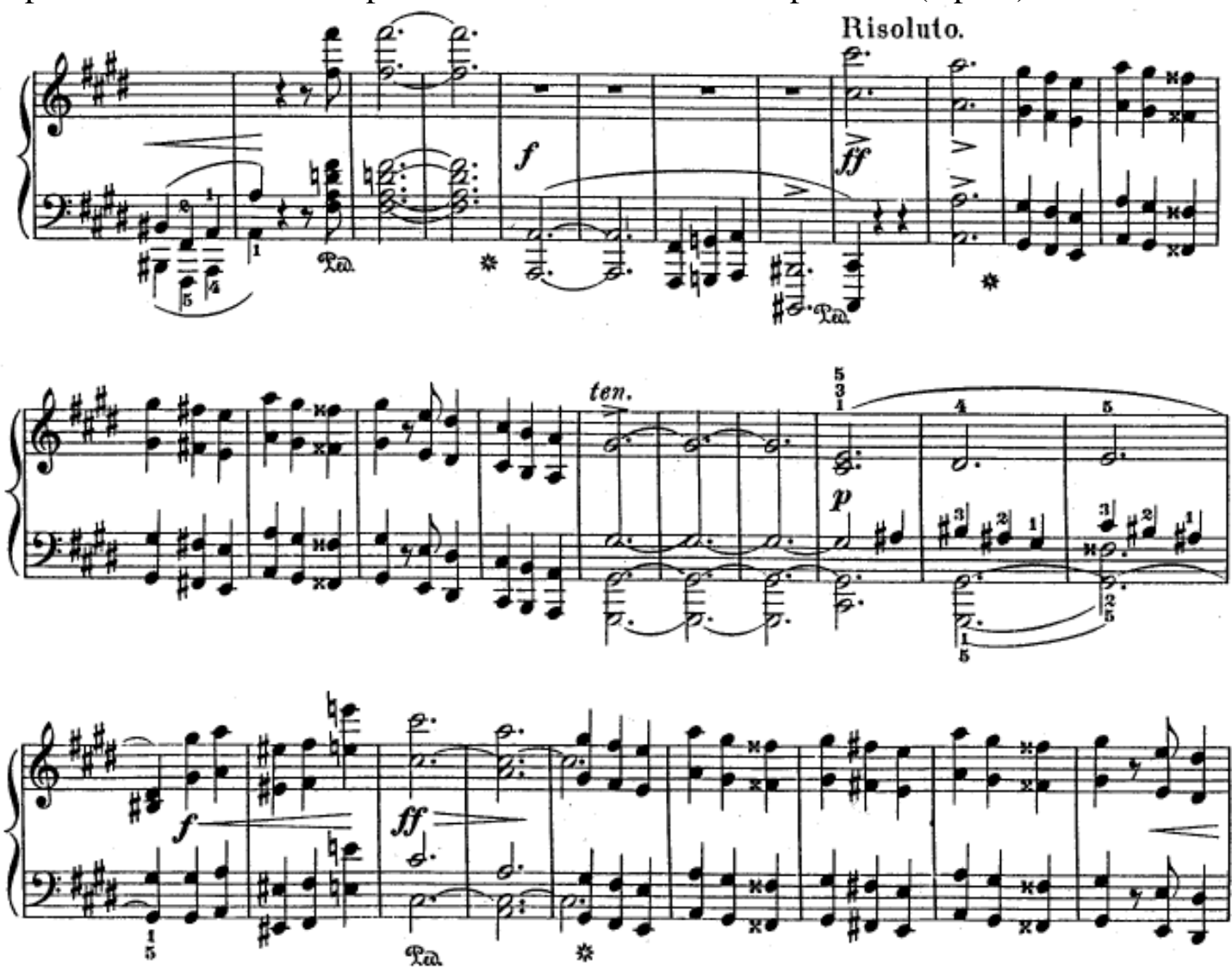

Fig. 2. Prelude theme melodic line of Chopin’s Third Scherzo of c Sharp Minor (Op.39)

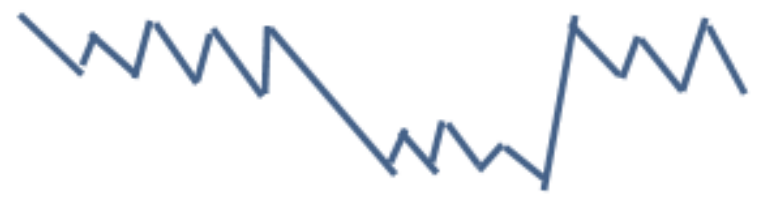

Kant in his Critique of Judgment points out that mechanical sublimity refers to giant power. He defines that strength is a kind of ability superior to great obstacle. If it is superior to the resistance which also has strength, it is called compelling force. When the natural world is taken as strength in aesthetic judgment but lacks compelling force for us, it is called the mechanical sublimity $\cdots$ make us show another kind of resistance and have encourage to fight against such kind of natural and superficial omnipotence. "Another kind of resistance" talked here refers to the strength more powerful than natural strength shown in spirit. In music, the concrete image of steep cliffs and destructive volcano can not be expressed like painting or literature, but the steep lines and rapid huge force with impact strength can be dynamically shown. The generation of sublimity in scherzos obtains spiritual victory through defeating such kind of destructive force.

In this work, we can also appreciate another form of sublimity. The melody of secondary theme imitates anthem and represents noble and holy sublimity. It uses the tone of psalmodic style to pursue the "melody" in Beethoven's heart which manifests kind-hearted people. In fact, anthem is the music 
Chopin once pursued at his early years. During his boyhood (in 1828), he was deeply fascinated by anthem. It is mentioned in Ates Orga's Chopin that:

"Once he was deeply touched by Handel's Ode for St. Cecilia's Day (created for solo, chorus and orchestra)". In a letter home written on September 20, he noted "the great music closest to my dream". It is intriguing that although Chopin was so fascinated by opera and anthem in his early years, he developed towards completely different musical orientation.

Even though "anthem” is not the main content of Chopin's music, anthem plays a decisive role in most of his works. As this scherzo, the anthem style melody of comparative theme has been purified and sublimated. It is a kind of ethic purpose at aesthetic and philosophical level.

In short, heroism and sublimity is a very significant characteristic in Chopin's scherzos. Heroes in his heart have been given more romantic colors rather than merely impeccable mythical heroes far away from people's life. They have become humanized romantic heroes with weakness, anticipation, desperation and endeavor. Heroes from the public will lose their power and even possibly die, unless they are able to find out the homeland in their heart and seek for strength and comfort here. Only in this way can their brave fighting capacity be constantly maintained.

\section{References}

[1] Charles Pierre Baudelaire (April 9, 1821-August 31, 1867), the most famous modernistic poet in the 19th century of France, pioneer of symbolistic poetry, master work as Flowers of Evil.

[2] Donald Jay Grout \&Claude Pliska A History of Western Music, Beijing: People's Music Publishing House, Edition of 1996, p 623.

[3] Literary Selections of Belinski, Book Two of the Third Volume, Edition of 1948 in Moscow, p 485.

[4] Kant, Translated by Deng Xiaomang, Critique of Judgment, People's Publishing House, Edition of 2002, p 113.

[5] Szabolesi Bence, History of Melody, Beijing: People's Music Publishing House, p180.

[6] Kant, Translated by Deng Xiaomang, Critique of Judgment, Beijing: People's Publishing House, Edition of 2002, p99.

[7] Li Xingchen, A Course Book of western Aesthetics History, Beijing: Peking University Press, Edition of 2005, p 219.

[8] Ates Orga, Translated by Jiang Jingling, Chopin, Jiangsu People's Publishing House, Edition of 1999, p 27. 